\title{
Cannabis-based medicines and the perioperative physician
}

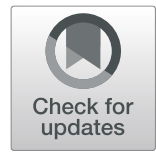

Patrick Tapley $^{1^{*}}$ (D) and Suzanne Kellett ${ }^{2}$

\begin{abstract}
The increasing availability of cannabis for both recreational and medicinal purposes means that anaesthetists will encounter an increasing number of patients taking cannabis-based medications. The existing evidence base is conflicted and incomplete regarding the indications, interactions and long-term effects of these substances. Globally, most doctors have had little education regarding the pharmacology of cannabis-based medicines, despite the endocannabinoid system being one of the most widespread in the human body. Much is unknown, and much is to be decided, including clarifying definitions and nomenclature, and therapeutic indications and dosing. Anaesthetists, Intensivists, Pain and Perioperative physicians will want to contribute to this evidence base and attempt to harness such therapeutic benefits in terms of pain relief and opiate-avoidance, anti-emesis and seizure control. We present a summary of the pharmacology of cannabis-based medicines including anaesthetic interactions and implications, to assist colleagues encountering these medicines in clinical practice.
\end{abstract}

Keywords: Pharmacology, Cannabis, Cannabinoids, Medical marijuana

\section{Introduction}

Cannabis use for medicinal purposes was first documented in 2900 BC in China, when Emperor Shen Nong described benefit for rheumatism and malaria (Pertwee 2015) and later in Ancient Egyptian texts (Pertwee 2015; Zlas et al. 1993). In the United Kingdom (UK), Queen Victoria's personal physician Sir John Russell Reynolds issued a tincture containing cannabis for her Majesty's menstrual cramps (David 2017), subsequently publishing his 30 years' worth of experience with the drug (Reynolds 1890).

Discussion in medical journals, the mainstream and social media around the use of cannabis for medicinal and nonmedicinal purposes has increased recently, especially following the legalisation of cannabis for recreational use in Canada (Government of Canada 2018a) and the UK government's decision to make cannabis-based medicines (CBMs) available for prescription by doctors on the specialist register (Department of Health and Social Care 2018).

The actual, social and economic legitimisation of cannabis and its medicinal derivatives makes it likely increasing numbers of patients will present on this class of

\footnotetext{
* Correspondence: paddytap@hotmail.com

${ }^{1}$ Department of Anaesthesia, Sunnybrook Health Sciences Centre, Bayview

Avenue, Toronto, Canada

Full list of author information is available at the end of the article
}

medicines. Perioperative physicians will require a sound understanding of their pharmacology and evidence base, and may wish to exploit this group of compounds for therapeutic purposes in the perioperative period.

A search of Pubmed was conducted in February 2019 utilising the search terms cannab* and the AND function for the following search terms individually; anaes*, marijuana, pain, nausea, surgery and pharmaco*. Abstracts were then screened for their applicability, with full texts reviewed. This was supplemented by a review of recent publications from governmental and regulatory organisations relating to CBMs, with backward reference searching. A search of individual governmental websites looking for legislation around cannabis and cannabinoid use was also undertaken in September 2019.

The pharmacology of novel psychoactive compounds ("legal highs") is outside the scope of this review.

\section{The global position}

The availability of CBMs varies geographically and there is no global consensus on how cannabis and CBMs should be regulated. International stakeholders and regulators, including the United Nations (International Drug Policy Consortium 2016; Transnational Institute and Global Drug Policy Observatory 2016) and World 
Health Organisation (WHO) have been inconsistent in their approach. The WHO's Expert Committee on Drug Dependences' recent review (Ghebreyesus 2019) recommended to the United Nations Office on Drugs and Crime (UNODC) that the rescheduling within the International Drug Control Conventions occurs for cannabis and cannabis resin, dronabinol, tetrahydrocannabinol and extracts and tinctures of cannabis. They also repeated their recommendation to remove cannabidiol (CBD) preparations (with not more than $0.2 \%$ delta-9$\mathrm{THC}$ ) from the International Drug Control Conventions. The UNODC subsequently delayed its vote on these recommendations, but despite this, many countries are proceeding to legalise or reschedule cannabis and/or CBMs, broadening public availability, with the UK the most recent country to reschedule CBMs. Table 1 details the current status of cannabis and CBMs in selected countries for medical use. The recreational use of cannabis is currently legalised in Uruguay, Canada and certain states within the USA (United Nations Office on Drugs and Crime 2019).

\section{Definitions of cannabis and cannabinoids Cannabis}

The Cannabis genus encompasses three major species; Cannabis sativa, Cannabis indica and Cannabis ruderalis. The number of identifiable extractable compounds has increased dramatically from 60 (Ashton 1999) to over 500 in the last 20 years (Beaulieu et al. 2016), of which over 100 are cannabinoids (Bie et al. 2018).

\section{Cannabinoids}

Cannabinoids are endogenous in humans, animals and plants, or synthetically produced, acting as ligands at the cannabinoid receptors. Cannabinoids can be psychoactive, for example delta-9-tetrahydrocannabinol (d9THC), delta8-tetrahydrocannabinol (d8THC), cannabinol (CBN) or non-psychoactive, for example cannabidiol (CBD). Table 2 lists their classification, as well as examples of currently available CBMs (Pertwee 2015; Beaulieu et al. 2016; Zendulka et al. 2016; Yeon Kong et al. 2018; Hauser et al. 2018a; Barnes 2018; National Institute for Health and Care Excellence 2014; Rice and Cameron 2017; Krcevski-Skvarc et al. 2018).

\section{Pharmacology of cannabinoids Mode of action}

The endocannabinoid system consists of both cannabinoid $(\mathrm{CB})$ receptors and neurotransmitters, the plasma concentrations of which are normally at low levels. They are synthesised in the postsynaptic neurone (Hosking and Zajicek 2008) in response to stimuli including pain, stress, inflammation and are involved in the homeostasis of various body systems (Pertwee 2015). Antinociceptive effects occur via their actions as retrograde transmitters at presynaptic inhibitory $\mathrm{CB}_{1}$ receptors (Hauser et al. 2018a). Both $C_{1}$ and $C_{2}$ receptors are $G$ protein coupled receptors $\left(G_{i}, G_{o}\right)$ with stimulation reducing cAMP production through the inhibition of adenylyl cyclase, resulting in an action on voltage gated calcium and potassium channels depressing neuronal excitability and reducing neurotransmitter release (Zendulka et al. 2016; Hauser et al. 2018a; Hosking and Zajicek 2008).

$\mathrm{CB}_{1}$ receptors are found in the cortex (thalamus, medulla, periaqueductal gray matter, descending pain pathways), spinal cord (descending pain pathways, dorsal horn) and peripherally on primary afferent sensory neurones where they outnumber the mu receptor, suggesting a potential mechanism for the modulation and treatment of neuropathic pain (Kumar et al. 2001).

$\mathrm{CB}_{2}$ receptors are involved in immunomodulation, with receptors distributed in the spleen, macrophages and Kupffer cells. It is increasingly recognised that the endocannabinoid system plays a crucial role in the maintenance of microglial activity through actions at $\mathrm{CB} 1$ and $\mathrm{CB} 2$ receptors, reducing neuro-inflammation (Bie et al. 2018; Bilkei-Gorzo et al. 2018). Relatively few $\mathrm{CB}_{2}$ receptors are found in the nervous system (Lucas et al. 2018), but they are inducible in the dorsal horn following inflammation or injury, with increased receptor concentration found in neuropathic pain models and receptor activation limiting the acute inflammatory process contributing to nociceptor sensitisation (Bie et al. 2018; Hosking and Zajicek 2008).

Exogenous and endogenous cannabinoids have differing effects at the $C_{1}$ and $C_{2}$ receptors. THC is an agonist at both, whilst $\mathrm{CBD}$ is a non-competitive antagonist at $\mathrm{CB}_{1}$ receptors at high concentrations, an inverse agonist at $\mathrm{CB}_{2}$ receptors and causes allosteric modulation of both CB receptors (Pertwee 2015; Lucas et al. 2018; Expert Committee on Drug Dependence 2018). The cannabinoid compounds, particularly CBD, have additional actions within the nervous system through signalling at a multitude of other receptors. This includes adenosine, serotonergic, adrenergic, nicotinic acetylcholine, glycine, nuclear peroxisome proliferator activated receptors (PPARs) and transient receptor potential (TPRV) ion channels (Capsaicin target). Anaesthetists should also note their actions at the opioid, NMDA and gamma amino butyric acid (GABA) receptors (Zendulka et al. 2016; Hauser et al. 2018a; Expert Committee on Drug Dependence 2018; Meng et al. 2017; Koppel et al. 2014).

\section{Opioid system interaction}

The cannabinoid and opioid systems are closely linked, with the activation of both opioid and cannabinoid 
Table 1 Current legal status of Cannabis and CBMs in selected countries

\begin{tabular}{|c|c|}
\hline Continent & Country \\
\hline $\begin{array}{l}\text { North } \\
\text { America }\end{array}$ & $\begin{array}{l}\text { America (United Nations Office on Drugs and } \\
\text { Crime 2019; Mead 2017; US Food and Drug } \\
\text { Administration 2016; Aguilar et al. 2018) }\end{array}$ \\
\hline
\end{tabular}

Canada (United Nations Office on Drugs and Crime 2019; Aguilar et al. 2018; Government of Canada 2018b; Health Canada 2018)

Mexico (Aguilar et al. 2018; Government of Mexico 2018a; Government of Mexico 2018b; Government of Mexico 2018c)

South Uruguay (United Nations Office on Drugs and America Crime 2019; Aguilar et al. 2018; Uruguay Government 2018)

Chile (Aguilar et al. 2018)

Brazil (Aguilar et al. 2018; Brazilian Government 2016)

Argentina (Aguilar et al. 2018; Argentinian government 2018; Government of Argentina 2019)

Oceania Australia (Aguilar et al. 2018; Australian Government Department of Health 2018; Therapeutic Goods Administration 2017)

New Zealand (Aguilar et al. 2018; New Zealand Parliament 2018; New Zealand Ministry of Health 2018)

Year Notes

approved

1996-

2017

Cannabis illegal under federal law, individual states have legalised to varying degrees

Medical use:

-Legalised by 33 states

-FDA has approved dronabinol (Marinol ${ }^{\circledR}$, Syndros ${ }^{\circledR}$ ), nabilone (Cesamet ${ }^{\circledR}$ ) and cannabidiol (Epidiolex ${ }^{\oplus}$ ) (CBMs) for specific indications, but cannabis plant not FDA approved

Recreational use:

-Legalised by 10 states (Alaska, California, Colorado, Maine, Massachusetts,

Michigan, Nevada, Oregon, Vermont, Washington) and District of Colombia for recreational use

- Illinois to be legalised January 12020

-Multiple states have bills in session to legalise recreational and medicinal cannabis and its products

-"Decriminalised" in numerous states (ie avoid jail term)

1999/ Medical use:

$2018 \quad$-Regulated by federal government

- Healthcare practitioner authorisation required

-Patients can access cannabis through federally licensed seller, designate someone to produce, or grow their own.

Recreational use:

-Cannabis for recreation legalised October 2018 under Cannabis Act

-Cannabis act permits sale of cannabis oil, fresh cannabis, dried cannabis,

cannabis plants and seeds

-Retailers must be authorised to sell cannabis

2017 Medical use:

Cannabis use allowed for medical and scientific purposes

Application required for import and use of cannabis and CBMs for medical purposes

Products with $<1 \% \mathrm{THC}$ recently marketed under Government authorisation with no prescription required

2013 Medical use:

-Prescription required for CBM for medicinal use

-Medicinal cannabis not authorised to be sold

-CMs accessible via specialist prescription

Recreational Use:

-Cannabis legalised and market regulated from December 2013 with strict controls

2015 Medical use

-Medical prescription required for medicinal cannabis

-CBM can be imported under special license

2014 Medical use:

-Imports of medications based on CBD oil for medical and therapeutic use for patients with prescription allowed

-Nabiximols (Sativex ${ }^{\oplus}$ ) licensed for MS

-Cannabis plant prescription prohibited

2017 Medical use:

-Prescription and government authorisation required through ministry of health

-State produced pharmaceuticals for domestic market

-Cannabis oils legal for import

2016 Medical use:

-cultivation, manufacture, prescribing and dispensing of medicinal cannabis products for patients now legal

-Access via authorised prescriber program, or special access scheme on individual patient basis. Must be prescribed

-Cannabis, THC, nabiximols (Sativex ${ }^{\circledR}$ ), dronabinol (Marinol ${ }^{\oplus}$ ), nabilone (Cesamet ${ }^{\oplus}$, Canemes ${ }^{\oplus}$ ) listed under schedule 8, require prescription -Cannabidiol listed under schedule 4, requires prescription

Medical use:

-Prescription required for most cannabis-based products, some require ministerial approval

-Nabiximols (Sativex ${ }^{\circledR}$ )and CBD based products available without ministerial 
Table 1 Current legal status of Cannabis and CBMs in selected countries (Continued)

\begin{tabular}{ll}
\hline Continent Country \\
\hline Europe $\quad \begin{array}{l}\text { Netherlands (Aguilar et al. 2018; Office of } \\
\text { Medicinal Cannabis 2018; Government of } \\
\text { the Netherlands 2019; Office of Medicinal } \\
\text { Cannabis Government of the Netherlands } \\
\text { 2019) }\end{array}$
\end{tabular}

Germany (Aguilar et al. 2018; Broich 2018)

Poland (Aguilar et al. 2018)

France (Aguilar et al. 2018; National Agency for the Safety of Medicines and Health Products 2013)

Ireland (Aguilar et al. 2018; Department of Health Ireland 2018; Health Products Regualtory Authority 2017)

UK (National Institute for Health and Care Excellence 2019; Dame Sally Davies 2018; National Health Service 2019)

Middle Israel (Aguilar et al. 2018)

East

Japan (Aguilar et al. 2018)

Pakistan (Aguilar et al. 2018)

Philippines (Aguilar et al. 2018; Republic of Phillipines House of Representatives 2018)

India (Aguilar et al. 2018; Indian Council of Medical Research 2018)

Africa South Africa (Department of Agriculture, Forestry and Fisheries 2018; Constitutional Court of South Africa 2017; Medicines Control Council 2016)

Year Notes

approved

approval

-Bill currently passing through NZ parliament to improve access

2000 Medical use:

-Medicinal use legalised in 2000

-Office of Medicinal Cannabis government agency responsible for supplying

medicinal cannabis to pharmacies, prescription required

-5 compositions produced, with varying strengths of THC and CBD

Recreational use:

-lllegal, but smoking cannabis under strict conditions allowed

2017 Medical use:

-Medicinal cannabis products able to be prescribed by physician

-CBMs included in range of medications covered by public and private

health insurance

2017 Medical use:

-Medicinal cannabis sold in registered pharmacies.

-Patients need permission from pharmaceutical inspector and physician

2013 Medical use:

-Law changed to allow marketing authorisation of products containing

cannabis or its derivatives

-Dronabinol (Marinol ${ }^{\circledR}$ ) approved and marketed

-Nabiximols (Sativex ${ }^{\oplus}$ ) approved but not marketed due to price

disagreements

Medical use:

-Cannabis for medical use access programme enables prescribing of

Cannabis for medical use by Medical Consultant

-Authorised CBMs (nabiximols (Sativex ${ }^{\oplus}$ ), dronabinol (Marinol ${ }^{\circledR}$ ), nabilone (Cesamet ${ }^{\circledR}$, Canemes ${ }^{\circledR}$ ) should be used in first instance with prescription

-Cannabis (plant or extracts not authorised as medicine) considered as treatment option

-Cannabidiol (Epidiolex ${ }^{\circledR}$ ) not currently authorised

2018 Medical use:

-CBMs recently rescheduled, only available via prescription from doctor on the specialist register

-Nabilone and Nabiximols (Sativex ${ }^{\circledR}$ ) currently licensed but the latter is not approved by NICE

-Dronabinol not available as a licensed medicine

-Cannabidiol not classed as CBM, and not controlled. Epidiolex ${ }^{\circledast}$ currently in licensing process.

-NICE draft guidance for prescription of CBMs currently open for public consultation

1992 Medical use:

-Medical Cannabis Unit established for the regulation of Cannabis

-Specialist physicians apply for Medical Cannabis permit on behalf of

patient

- > 40,000 patients receiving medicinal cannabis

Prohibited

Prohibited

2016 Medical use:

-Cannabis allowed with prior authorisation from a doctor and treatment delivered in dedicated centres

-Covers all forms of Cannabis, no specific mention CBMs

Medical use:

-Legal provisions for medicinal use yet to be implemented

-Council of Scientific and industrial research currently undertaking research into medical benefits

2018 Medical use:

-Special authorisation from Medical Control Council by physician can be requested for prescription of medicinal cannabis products

-Cannabidiol preparations excluded from Medicines and related substances act 
Table 2 Classification of cannabinoids and some commercially available preparation

\begin{tabular}{|c|c|c|c|c|c|c|}
\hline Group & $\begin{array}{l}\text { Where } \\
\text { found }\end{array}$ & Major known Compounds & $\begin{array}{l}\text { Substance } \\
\text { found in }\end{array}$ & $\begin{array}{l}\text { Trade } \\
\text { name }\end{array}$ & $\begin{array}{l}\text { Route of } \\
\text { administration }\end{array}$ & Current uses \\
\hline $\begin{array}{l}\text { Endo } \\
\text {-cannibinoid }\end{array}$ & $\begin{array}{l}\text { Endogenous } \\
\text { within body }\end{array}$ & $\begin{array}{l}\text {-Arachidonoyl ethanolamide (Anandamide) } \\
\text {-2-arachidonylglycerol (2-AG) } \\
\text {-Docosatetraenoyl-ethanolamide (DEA), } \\
\text {-N-arachidonyldopamine (NADA), } \\
\text {-Virodhamine, } \\
\text {-2-arachidonylglyceryl, } \\
\text {-noladin ether } \\
\text {-dihomo- gamma-linolenoylethanolamide } \\
\text { (HEA). }\end{array}$ & & & & \\
\hline \multirow[t]{4}{*}{$\begin{array}{l}\text { Synthetic } \\
\text { cannabinoids }\end{array}$} & \multirow[t]{4}{*}{$\begin{array}{l}\text { Chemically } \\
\text { synthesised }\end{array}$} & \multirow[t]{2}{*}{$\begin{array}{l}\text { Synthetic THC } \\
-(-) \text { trans isomer of delta } 9 \text { THC }\end{array}$} & \multirow[t]{2}{*}{ Dronabinol } & Marino $^{\oplus}$ & $\begin{array}{l}\text { Oral capsule } \\
\text { (formulated in } \\
\text { sesame oil) }\end{array}$ & $\begin{array}{l}\text { US; FDA approved; } \\
\text {-anorexia associated weight loss } \\
\text { in AIDS patients } \\
\text {-chemo induced nausea and } \\
\text { vomiting * } \\
\text { UK; not available }\end{array}$ \\
\hline & & & & Syndros ${ }^{\circledast}$ & $\begin{array}{l}\text { Liquid } \\
\text { formulation }\end{array}$ & $\begin{array}{l}\text { US; FDA approved } \\
\text { - anorexia associated weight } \\
\text { loss in AIDS patients } \\
\text {-chemo induced nausea and } \\
\text { vomiting * }\end{array}$ \\
\hline & & Synthetic THC analogue (single molecule) & Nabilone & Cesamet $^{\oplus}$ & Oral capsule & $\begin{array}{l}\text { US; FDA approved chemo } \\
\text { induced nausea and vomiting } \\
\text { UK; -chemo induced nausea and } \\
\text { vomiting * }\end{array}$ \\
\hline & & $\begin{array}{l}\text { Variety; mainly aminoalkylindole } \\
\text { derivatives ie JWH-018, UR-144, PB-22 }\end{array}$ & Legal highs & $\begin{array}{l}\text { Spice, K2, } \\
\text { eclipse }\end{array}$ & $\begin{array}{l}\text { Oral } \\
\text { Smoked }\end{array}$ & \\
\hline \multirow[t]{6}{*}{$\begin{array}{l}\text { Phyto } \\
\text {-cannibinoid } \\
\text { (plant derived) }\end{array}$} & \multirow{6}{*}{$\begin{array}{l}\text { Cannabis } \\
\text { genus; } \\
\text {-cannabis } \\
\text { sativa, } \\
\text {-cannbis } \\
\text { indica } \\
\text {-cannabis } \\
\text { ruderalis }\end{array}$} & $\begin{array}{l}\text { THC content varies } 1-22 \% \\
\text { CBD content varies } 0.05-9 \%\end{array}$ & $\begin{array}{l}\text { Cannabis; } \\
\text { Marijuana }\end{array}$ & & $\begin{array}{l}\text { Inhalation } \\
\text { (commonly } \\
\text { smoked) }\end{array}$ & $\begin{array}{l}\text { UK; Illegal } \\
\text { US; legalised for medical use } \\
\text { in } 29 \text { states, recreational use } \\
\text { in } 9 \text { states }\end{array}$ \\
\hline & & $\begin{array}{l}\text { THC content varies } 1-22 \% \\
\text { CBD content varies } 0.05-9 \%\end{array}$ & $\begin{array}{l}\text { Cananbis; } \\
\text { Hashish }\end{array}$ & & Oral & $\begin{array}{l}\text { UK; Illegal } \\
\text { US; legalised for medical use } \\
\text { in } 29 \text { states, recreational use } \\
\text { in } 9 \text { states }\end{array}$ \\
\hline & & \multirow[t]{2}{*}{ Pure CBD (no psychoactive properties) } & \multirow[t]{2}{*}{ Cannabidiol } & & $\begin{array}{l}\text { Oral capsule } \\
\text { Oromucosal } \\
\text { spray }\end{array}$ & \\
\hline & & & & Epidiolex & Oil & $\begin{array}{l}\text { US;FDA approved for treatment } \\
\text { resistant epilepsy }\end{array}$ \\
\hline & & 2.7mg THC and 2.5mg CBD per spray & Nabiximols & Sativex ${ }^{\circledast}$ & $\begin{array}{l}\text { Oromucosal } \\
\text { spray }\end{array}$ & $\begin{array}{l}\text { US; not approved. Approved } \\
\text { in } 30 \text { other coutnrie } \\
\text { UK; MHRA but not NICE approved. } \\
\text { MS induced spasticity }\end{array}$ \\
\hline & & $2.5 \mathrm{mg}$ THC, $1.25 \mathrm{mg}$ CBD & Cannador & & Oral capsule & German based research only \\
\hline
\end{tabular}

${ }^{*}$ not responded to conventional antiemetics

receptors mediating common intracellular signalling mechanisms (Manzanares et al. 1999; Abrams et al. 2011; Scavone et al. 2013; Cohen et al. 2019; Pertwee et al. 2010). Opioid and cannabinoid receptors are found within the same cells and neurones in the central nervous system, with cannabinoids acting at kappa and delta receptors to increase endogenous opioid synthesis and release. Notably, the administration of opioid antagonists has been shown to block some of the effects of delta 9THC (Manzanares et al. 1999). The presence of opioid and cannabinoid receptors in noradrenergic pathways may have a role in the treatment of opiate withdrawal (Scavone et al. 2013).

\section{NMDA system interaction}

The NMDA receptor NR1 subunit is closely coupled to CB1 receptors, with the histidine triad nucleotide binding protein 1 (HINT 1) thought to be the pivotal modulator, exerting a negative control on NMDA receptors. HINT-1 gene deletion results in loss of CB1 inhibition of the NMDA receptor (Rodríguez-Muñoz et al. 2016). 
CB1 receptors have both presynaptic (reduced release of glutamate into synaptic cleft) and post-synaptic (intracellular NMDA signalling) effects (Rodríguez-Muñoz et al. 2016).

NMDA receptor activity stimulates the release of endocannabinoids, resulting in negative feedback reducing NMDA receptor numbers. It has been postulated that exo-cannabinoids are more potent inhibitors of the NMDA receptor than endocannabinoids (Pacheco et al. 2019; Ferreira et al. 2018), with exo-cannabinoids causing neural dysfunction and NMDA receptor hypofunction through alteration in the balance of NMDA-CB receptor regulation (Rodríguez-Muñoz et al. 2016).

The endocannabinoid system also regulates NMDA receptor activity by preventing over activation, neuroprotection from excitotoxicity and downregulating their activity (Rodríguez-Muñoz et al. 2016; Pacheco et al. 2019; Sánchez-Blázquez et al. 2014).

\section{Gamma amino butyric acid}

Gamma amino butyric acid (GABA) and CB1 receptors are closely localised in multiple cortical regions, including the hypothalamus, hippocampus and cortex (Cohen et al. 2019; Lotsch et al. 2018). CB1 receptors are expressed on GABAergic neurons, helping to regulate astrocyte and microglial activity, and hence neuroinflammation (Bilkei-Gorzo et al. 2018).

In preclinical studies, cannabinoids inhibit GABA release, through activation of $\mathrm{CB} 1$ receptors (Pertwee 2015; Laaris et al. 2011). They inhibit GABA uptake from the CNS extracellular space (Laaris et al. 2011), and cause allosteric modulation of GABA receptors (Bakas et al. 2017). Limited human studies show altered levels of GABAergic functions with chronic cannabis use, which may contribute to psychological effects (Cohen et al. 2019).

\section{Pharmacokinetics Absorption}

The absorption of vaporised cannabinoids is rapid, with peak plasma concentrations observed within $10 \mathrm{~min}$. THC's bioavailability after inhalation ranges from 10 to $35 \%$, and CBD 31\% varying with device used and size of the particles (Kumar et al. 2001; Lucas et al. 2018; Karschner et al. 2011).

Oral bioavailability of CBM is low, at $2-20 \%$ for both CBD and THC (Lucas et al. 2018; Karschner et al. 2011; Anderson and Chan 2016) mainly due to extensive first pass metabolism (Lucas et al. 2018). Onset of action is $0.5-2 \mathrm{~h}$ due to slow intestinal absorption resulting in a longer duration of action (Kumar et al. 2001; Bridgeman and Abazia 2017).

An oromucosal spray preparation (nabiximols; Sativex

-) has a reported bioavailability similar to oral THC or intermediate between the oral and inhaled routes (Lucas et al. 2018; Expert Committee on Drug Dependence 2018; Karschner et al. 2011; Anderson and Chan 2016).

Transdermal administration is reported, with the permeability of CBD and CBN higher than d9THC and d8THC (Therapeutic Goods Administration 2017), but their hydrophobic nature means transdermal absorption is poor and requires permeation enhancement (Lucas et al. 2018).

\section{Distribution}

Volume of distribution varies by cannabinoid studied, with a $V_{D}$ of $32 \mathrm{~L} / \mathrm{kg}$ for CBD (intravenous administration), and $3.4 \mathrm{~L} / \mathrm{kg}$ for THC (inhalation administration) (Lucas et al. 2018), which is said to follow a three-compartment model (Heuberger et al. 2015). Cannabinoids are highly lipid soluble (Kumar et al. 2001) with rapid penetration through the blood-brain barrier (Ashton 1999), the placenta and into breast milk (Lucas et al. 2018). This also leads to accumulation in fatty tissue, with continued activity following cessation.

\section{Metabolism}

The cannabinoids are mainly hydroxylated and glucuronidated in the liver by the cytochrome P450 family of isoenzymes (Kumar et al. 2001; Lucas et al. 2018; Karschner et al. 2011; Ujváry and Hanuš 2016). Some metabolites are equipotent to the parental compounds (Yeon Kong et al. 2018; Rong et al. 2017). THC is metabolised to over 80 metabolites by various isoenzymes, including CYP1A1, CYP1A2, CYP1B1, CYP2B6, CYP2A6, CYP2C9 and CYP3A4. Inhibition of CYP3A4 may result in clinically apparent interactions with oxycodone (Pertwee 2015; Zendulka et al. 2016; Hauser et al. 2018a; Lucas et al. 2018).

CBD is metabolised to over 100 metabolites by isoenzymes CYP1A1, CYP1A2, CYP3A4, CYP2C9 and CYP2D6, the most abundant metabolite being the hydroxylated 7-COOH CBD derivative (Lucas et al. 2018; Ujváry and Hanuš 2016). Inhibition of CYP2D6 and CYP3A4 results in interactions with oxycodone, benzodiazepines and haloperidol (Hauser et al. 2018a; Karschner et al. 2011; Ujváry and Hanuš 2016). Oral CBD increases clobazam (and active metabolite) plasma levels (CYP2C19 interaction) (Ujváry and Hanuš 2016), resulting in dose reductions of clobazam in recent randomised controlled trial (RCTs) (Thiele et al. 2018). Prolonged use of CBD results in CYP1A1 induction (Ujváry and Hanuš 2016).

Cannabinol is metabolised via CYP2C9 and CYP3A4, with no evidence cytochrome P450 interactions (Zendulka et al. 2016).

The significance of these interactions is uncertain as they have occurred either in vitro or in excess of clinically relevant concentrations. 


\section{Elimination/excretion}

Clearance of cannabinoids is estimated to be $38.8 \mathrm{~L} / \mathrm{h}$ to $53 \mathrm{~L} / \mathrm{h}$ (Heuberger et al. 2015), with long terminal halflives due to their lipophilicity. In regular users, this is extended, with measurable plasma concentrations of THC over $24 \mathrm{~h}$ after last administration. Fifteen percent of cannabinoid metabolites undergo enterohepatic recycling, prolonging their action (Ashton 1999).

THC and metabolites are mainly excreted in faeces (65-80\%) and urine (20-35\%) (Ashton 1999; WHO Expert Committee on Drug Dependence 2018). THC's elimination half-life is $56 \mathrm{~h}$ in occasional and $28 \mathrm{~h}$ in chronic users (Ashton 1999) with urinary metabolites measurable 14 days post exposure (Vandrey et al. 2017). Nabilone's (Cesamet "; synthetic THC) elimination halflife is shorter than THC, at $2-4 \mathrm{~h}$, yet $16 \%$ of a single dose is reportedly measurable at 7 days post administration (Ashton 1999).

CBD metabolites and unchanged drug are mainly excreted in the urine with an elimination half-life of $2-5$ days (Lucas et al. 2018; Anderson and Chan 2016; Ujváry and Hanuš 2016).

\section{Pharmacodynamics (of relevance to the perioperative physician) \\ Cardiovascular system}

Tachycardia due to $\mathrm{CB}_{1}$ agonism in cardiac myocytes has been reported (Kumar et al. 2001; Lucas et al. 2018), but was not noted following intravenous administration of d9THC (Vandrey et al. 2017). Bradycardia, hypotension, an increased cardiac output and myocardial oxygen demand have been described (Dickerson 1980; Bryson and Frost 2011). These effects are potentially exacerbated by sympathomimetic agents although the mechanism of action is unclear (Lucas et al. 2018). Effects may be cannabinoid specific, with CBD (Expert Committee on Drug Dependence 2018) not reported to effect heart rate or blood pressure, and THC possibly having anticholinergic effects through depletion of acetylcholine stores (Dickerson 1980).

\section{Central nervous system}

Effects are well described largely in relation to their abuse as a recreational drug, including psychomotor impairment, sedation, dizziness, euphoria, disorientation and confusion. Effects may be enhanced if administered with other CNS depressant drugs, for example opioids or benzodiazepines, and have been observed in a clinical setting (Kumar et al. 2001; Lucas et al. 2018).

The behavioural and long-term psychological effects (including dependence) of cannabis are widely reported (Pertwee 2015; Kumar et al. 2001; Nugent et al. 2017), and not reiterated here. Some evidence suggests the abuse potential of CBMs, likelihood of withdrawal phenomena and mental health morbidity is low (Pertwee
2015; Aragona et al. 2009), but trials are of short duration and do not examine long term effects. Evidence suggests chronic cannabis use impairs learning, memory and attention, and causes complex mental health disorders (Pertwee 2015; Nugent et al. 2017; National Academies of Sciences Engineering and Medicine 2017; Campbell et al. 2018). Further research is needed to determine relevance to CBM use.

\section{Respiratory system}

There is no clear evidence of respiratory system effects when administered by routes other than smoking. This may be due to the absence of cannabinoid receptors in the brainstem (Kumar et al. 2001).

Perioperative practitioners should be alert to the recent warning from the FDA around the use of vaping THC oil (US Food and Drug Administration 2019). This followed on from a multitude of reports of severe pulmonary disease development associated with vaping of THC products (Layden et al. 2019). Any patient presenting in the perioperative period with new onset respiratory disease and a history of vaping THC should therefore be thoroughly evaluated with this kept in mind.

\section{Immune system}

Animal studies suggest that high-dose cannabinoids impair cell-mediated and humoral immunity (Kumar et al. 2001), and low-dose CBD causes immune stimulation (Expert Committee on Drug Dependence 2018). The clinical relevance in humans is unclear.

\section{Interactions of note for the perioperative physician} Induction agents/volatiles

Effects of cannabinoids on dosing of volatile and intravenous anaesthetic agents is equivocal, with evidence limited to animal studies, case reports and two limited human studies.

Ether anaesthesia is prolonged in mice and rats by cannabidiol, d8THC and d9THC (Chesher et al. 1974). Halothane anaesthesia is prolonged and dose requirements reduced in dogs after THC administration (Stoelting et al. 1973), with similar effects noted in mice with isoflurane administration (Schuster et al. 2002). Little is known about the interaction between cannabinoids and modern inhalational anaesthetics.

Animal studies have shown cannabidiol, d8THC and d9THC prolong barbiturate anaesthesia in mice and rats (Chesher et al. 1974) and THC administration increases the doses of thiopentone and propofol required for sedation (Brand et al. 2008). A cannabis extract premedication in dogs resulted in quicker onset and longer lasting anaesthesia with propofol (Kumar et al. 2010). One 
postulated mechanism is the increased Andamide (endocannabinoid) levels in the brain with propofol, with the inhibition of the enzyme fatty acid amide hydrolyses (FAAH), which normally terminates Anandamides activity, thought to be key (Schelling et al. 2006).

There is limited evidence of the effect of cannabinoid exposure on anaesthesia in humans. Case reports suggest increased anaesthetic requirements with non-medicinal cannabis use (Richtig et al. 2015; Symons 2002). A prospective trial found significantly increased propofol dosing for induction and LMA insertion in cannabis users versus controls (Flisberg et al. 2009). Studies utilising bispectral index monitoring (BIS) found no differences between cannabis users and non-users with the bolus dose of propofol required to achieve a BIS of $<60$ (Flisberg et al. 2009). Higher BIS values have been noted for patients under steady state volatile anaesthesia who were administered nabiximols $\left(\right.$ Sativex $^{\circ}$ ) as a premedication versus controls (Ibera et al. 2018).

These results should be interpreted cautiously given the limited number of participants, the applicability of extrapolating animal studies to human practice, use of unknown quantities of non-prescribable CBMs (except one study) and uncertainties about prior cannabis consumption (Flisberg et al. 2009). Additionally in the electroencephalogram (EEG)/depth of anaesthesia studies, it is unclear if the effects are a result of cannabinoids on the EEG or the effect of cannabinoidanaesthetic interaction.

In summary, there is minimal evidence base as to the effects of the current agents, with animal studies relating to older agents only (ether, halothane, isoflurane). The evidence for intravenous agents is conflicting and of poor quality, but propofol requirements may be higher. There is a current research opportunity for investigation into the interaction with newer agents in humans.

\section{Opioids}

Cannabinoid agonists facilitate endogenous opioid signalling and increase concentrations of endogenous opioids (Scavone et al. 2013; Abrams 2016).

In animal studies (Abrams 2016; Maguire and France 2018), cannabinoids and opioids are synergistic, with the analgesic efficacy of cannabinoids not reduced when opioid antagonists are administered. Human findings are variable; statistically significant reductions in pain scores, and similar opioid pharmacokinetics (with the exception of a reduced $\mathrm{C}_{\max }$ in the morphine group) pre and post vaporised cannabis use was found in chronic opioid users (morphine/oxycodone) (Abrams et al. 2011). In contrast, a small study found higher pain scores and greater rescue analgesia requirements post operatively in cannabis users, versus non-cannabis users (Jefferson et al. 2013). Chronic cannabinoid and cannabis users undergoing orthopaedic procedures showed higher postoperative pain scores without a significant increase in post-operative opioid consumption (Liu et al. 2018). All these studies have limited numbers of participants, and methodological issues that may confound the results.

In summary, cannabinoids and opioids are synergistic for both wanted and unwanted effects. Chronic cannabis users may have higher pain scores; it is unclear whether this is pathophysiological or a behavioral component of drug use.

\section{Ketamine}

Ketamine induces endogenous cannabinoid release (Pacheco et al. 2019; Ferreira et al. 2018), which may partially explain its role in anti-nociception. The psychomotor side effects of ketamine are enhanced with CBD administration, but no adverse behavioural or cardiovascular effects have been noted (Hallak et al. 2011).

\section{Gabapentinoids}

Gabapentin's mechanism of action is via $\alpha 2 \delta$ subunits on voltage-dependent calcium channels, with reduction in neural transmission. Similarly, activation of the CB receptor results in inhibition of the voltage dependent calcium channel (Pertwee 2015; Lile et al. 2016). Animal studies have shown the synergistic action of gabapentin and THC when used for the treatment of neuropathic pain, at the expense of increased side effects of THC (Atwal et al. 2017).

Human studies are limited; in multiple sclerosis, the combination of $\mathrm{THC}$ and gabapentin improved pain scores in neuropathic pain (Turcotte et al. 2015). Highdose gabapentin for management of cannabis tolerance produces THC like effects, and when gabapentin was used in combination with THC, these effects were seen to be increased, suggesting overlap of pharmacological actions (Lile et al. 2016).

In summary, the gabapentinoids and cannabinoids have overlapping pharmacological actions, with increased therapeutic and side effects when combination dosing is used.

\section{Dexmedetomidine}

There is limited evidence regarding potential interactions between cannabinoids and Dexmedetomidine. Animal studies have shown that a synthetic THC derivative $(\mathrm{CP} 55,940)$ has additive or synergistic analgesic effects when administered with Dexmedetomidine, depending on the nociceptive stimulus utilised (Tham et al. 2005). The study failed to explain the mechanism of this apparent synergy; however, given the similar intracellular signalling mechanisms (calcium, potassium and cyclic AMP) activated by these medications and the close locality of the target receptors in the periaqueductal grey and substantia gelatinosa, receptor interaction is postulated (Tham et al. 2005). 
Given the lack of current evidence around interactions in humans, further research should focus on this area.

\section{Medical conditions where cannabinoids are recommended}

A variety of National and Governmental organisations have provided reviews on the use of CBMs, producing recommendations with a varying hierarchy of evidence (Department of Health and Social Care 2018; Ghebreyesus 2019; Therapeutic Goods Administration 2017; Health Products Regualtory Authority 2017; National Academies of Sciences Engineering and Medicine 2017). Here, we review the commoner indications for CBMs.

\section{Chronic pain}

Information on the use of cannabinoids for chronic pain comes from trials, systematic reviews (SR), meta-analyses (MA) and organisational reports. The outcomes vary, and are limited by factors including study design, moderate to high risk of bias (Hauser et al. 2018a), limited participants (most recent SR/MA (Stockings et al. 2018a) identified 104 studies, 21 with $>100$ participants), short duration of exposure to the cannabinoid (median eight weeks (Stockings et al. 2018a)) and varying definitions of "chronic pain". Many studies within these systematic reviews are notable for high withdrawal rates in the treatment arms (Stockings et al. 2018a; Mucke et al. 2018).

The most recent SR concluded that the number needed to harm (NNTH) for cannabinoid use in chronic pain was 6 (opioids NNTH $=5$ ) (Stockings et al. 2018a) with a number needed to treat (NNT) of 24 (30\% reduction in pain). This compares unfavourably with opioids (NNT 4.3), pregabalin (7.7) and tricyclics (NNT 3.6) (Stockings et al. 2018a). When the pain intensity reduction (versus placebo) was pooled, it was equivalent to a 3 $\mathrm{mm}$ reduction on a $100 \mathrm{~mm}$ visual analogue scale. Taken with a higher risk of an adverse event and trial withdrawal (Stockings et al. 2018a), the authors suggested that whilst there was moderate evidence for pain reduction with cannabinoids compared with placebo (higher quality evidence for MS and neuropathic related pain), it seemed unlikely that cannabinoids are highly effective for chronic non-cancer pain.

Other SR/MAs make varying comments on the strength of the evidence, including weak recommendations (Meng et al. 2017), low strength (Rodríguez-Muñoz et al. 2016), moderate (Therapeutic Goods Administration 2017; Mucke et al. 2018; Whiting et al. 2015) (30\% reduction pain relief), moderate to high (Aviram and Samuelly-Leichtag 2017), strong or "conclusive" (Abrams 2018) evidence for the use of cannabinoids in chronic pain. Others suggest a moderate to high risk of bias, concluding the evidence base is insufficient to make well found conclusions about the use of CBMs for cancer and non-cancer pain (Hauser et al. 2018b). Additionally, a large observational cohort study in Australia disputed cannabis use as an adjunct to reduce opiate consumption (Sánchez-Blázquez et al. 2014).

Globally, regulatory bodies have come to different conclusions. The Health Products Regulatory Authority (HPRA) of Ireland does not support CBMs as a treatment in chronic pain (Health Products Regualtory Authority 2017). The European Pain Federations recent position paper recommended CBMs be considered for chronic neuropathic pain, but as a third line agent, and stated there was insufficient evidence for CBMs for nonneuropathic chronic non-cancer pain (Hauser et al. 2018a). This is in direct contrast to the National Academies of Science Engineering and Medicine (NASEM) review on the health effects of cannabis and cannabinoids (National Academies of Sciences Engineering and Medicine 2017) which concluded that there was conclusive or substantial evidence for the use cannabis or cannabinoids for the treatment of pain in adults.

In summary, CBMs have a higher NNT than opioids, pregabalin or TCA, with a clinically insignificant pooled pain reduction of $3 \mathrm{~mm}$ on $100 \mathrm{~mm}$ VAS, and are thus unlikely to be effective in chronic, non-cancer pain, non-neuropathic pain. Additionally, other problems include study design and high withdrawal rates in intervention arms, with Cannabinoids demonstrating a higher risk of adverse events.

\section{Nausea and vomiting secondary to chemotherapy}

Nabilone (UK) and dronabinol (USA) are used to treat intractable post-chemotherapy nausea and vomiting (Abrams 2018), with the HPRA of Ireland recently permitting its use for this indication (Health Products Regualtory Authority 2017).

Reviews of cannabinoids for this indication have found them to be better than placebo (Whiting et al. 2015; Smith et al. 2015; Layeeque et al. 2006) of similar (Smith et al. 2015; Lewis et al. 1994) or better efficacy than antiemetics (dopamine antagonists) (Whiting et al. 2015), but with patients preferring CBMs (Smith et al. 2015). These reviews do not compare CBMs with steroids or serotonin $\left(5 \mathrm{HT}_{3}\right)$ antagonists. One randomised controlled trial utilising ondansetron as a comparator (Meiri et al. 2007) was stopped early due to recruitment difficulties, and had numerous methodological limitations including being underpowered for the authors conclusion that dronabinol was as efficacious as ondansetron.

The quality of evidence for the use of CBMs in preventing chemotherapy induced nausea and vomiting has been described as low (Whiting et al. 2015; Smith et al. 2015), "sometimes effective" (Therapeutic Goods Administration 2017) or conclusive/substantial evidence of benefit (Abrams 2018). 
In summary, no completed studies have utilised modern antiemetics as a comparator, but cannabinoids are better than placebo, and display equivalent efficacy with dopamine antagonists. Further research will help determine the appropriate usage of CBM for nausea and vomiting.

\section{Multiple sclerosis}

Nabiximols $\left(\right.$ Sativex $\left.^{\circ}\right)$ is licensed for multiple sclerosis (MS)-induced spasticity (Department of Health and Social Care 2018), which affects $17 \%$ of MS sufferers, with a similar proportion using cannabis for symptom control (Rice and Cameron 2017).

Previous MA/SR have produced various conclusions on the strength of the evidence of CBMs in MS-induced spasticity, ranging from low quality to conclusive evidence (Therapeutic Goods Administration 2017; Health Products Regualtory Authority 2017; Rice and Cameron 2017; Koppel et al. 2014; Whiting et al. 2015; Abrams 2018). A recent systematic review of reviews (Nielsen et al. 2018) for the use of cannabinoids in MS concluded that whilst the quality of the evidence from included studies was very low to low, five of the eleven reviews concluded that there was sufficient evidence for reduction in spasticity and/or pain in MS. However, the authors stated that despite the positive findings, the effect was small (Nielsen et al. 2018).

In summary, CBMs have a small positive effect on muscle spasticity, but the evidence quality is low.

\section{Epilepsy}

The United States Food and Drug Administration (FDA) (US Food and Drug Administration 2018) has recently approved cannabidiol oral solution (Epidiolex ${ }^{\circ}$ ) for the treatment of two forms of rare epilepsy in children aged over 2 years of age; Lennox-Gastaut syndrome and Dravet syndrome (Thiele et al. 2018; Devinsky et al. 2018; Devinsky et al. 2017). Most evidence is on the use of CBD, with the overall quality of the evidence in adults being limited (Koppel et al. 2014; Abrams 2018; Gloss and Vickrey 2014; Stockings et al. 2018b). Meta-analysis results pool effects in adults and children, with conclusions being influenced by the aforementioned paediatric studies (Sánchez-Blázquez et al. 2014; Devinsky et al. 2018; Devinsky et al. 2017; Gloss and Vickrey 2014; Stockings et al. 2018b). Outside of the USA, CBM use for epilepsy is not recommended in the UK (Department of Health and Social Care 2018), Ireland (Health Products Regualtory Authority 2017) and only once conventional treatments have failed in Australia (Therapeutic Goods Administration 2017).

In summary, the evidence base supports the use of CBD in children with certain neurological conditions, but not in adults.

\section{Other}

The NASEM review has considered CBMs for the treatment of other conditions, as detailed in Table 3 (Abrams 2018).

\section{Potential future uses in perioperative medicine Nausea and vomiting prophylaxis and treatment}

There is a paucity of evidence on the effects on postoperative nausea and vomiting (PONV). Nabilone (Cesamet $^{\circ}$ ) (Lewis et al. 1994; Levin et al. 2017) and intravenous THC (Kleine-Brueggeney et al. 2015) have been shown to be ineffective for PONV. Nabilone premedication compared with placebo (Levin et al. 2017) or metoclopramide (Lewis et al. 1994) had no effect on PONV. Intravenous THC similarly showed a lack of effect, with early trial cessation due to an intolerable side effect profile (Kleine-Brueggeney et al. 2015).

Combination therapy (dronabinol and prochlorperazine) compared with routine care showed a reduction in the incidence of PONV, yet the retrospective nature and multiple confounders means the evidence has to be carefully interpreted (Layeeque et al. 2006).

\section{Perioperative pain management}

A systematic review looking at the efficacy of cannabinoids for acute pain management suggested no role for cannabinoids (Stevens and Higgins 2017).

For perioperative pain management, a small number of RCTs have been conducted with two studies suggesting benefit (Jain et al. 1981; Holdcroft et al. 2006). The first (Jain et al. 1981) showed significantly improved post-

Table 3 Potential indications for CBM and evidence base

\begin{tabular}{ll}
\hline Evidence of benefit & Condition \\
\hline Moderate & -Improving short-term sleep in sleep disturbance associated with \\
Limited & OSA, Chronic pain, MS \\
& -Improving symptoms of post-traumatic stress disorder, anxiety \\
& -Improving appetite and decreasing weight loss associated with \\
None & HIV/AIDS \\
& -Tourette syndrome \\
& -Treatment of cancer \\
& -Irritable bowel syndrome symptoms \\
& -Neurodegenerative conditions \\
\hline
\end{tabular}


operative pain scores compared with placebo, but at the expense of increased side effects including drowsiness and dysphoria. The second (Holdcroft et al. 2006), a dose escalation study, with an oral capsule mixture of THC/cannabidiol (and other plant-based cannabinoid extracts) reported a similar NNT as other rescue analgesics, but with significantly increased side effects including sedation and nausea. The applicability of these results is limited by methodological issues and the small number of participants.

Six other studies (Ostenfeld et al. 2011; Beaulieu 2006; Buggy et al. 2003; Seeling et al. 2006; Kalliomäki et al. 2013; Guillaud et al. 1983) investigating the perioperative use of CBMs for analgesia showed no improvement in pain scores; one (Beaulieu 2006) showing significantly higher pain scores.

If CBMs are to be introduced into the clinical pharmacopoeia for perioperative analgesia, the potential for synergy with concurrently administered opioids (especially slow release formulations) in the perioperative period should be considered. One of the main concerns, and as recently highlighted by both the Anaesthesia Patient Safety Foundation (APSF) and ANZCAs faculty of pain medicine (Anaesthesia Patient Safety Foundation 2018; Australia and New Zealand College of Anaesthetists Faculty of Pain Medicine 2018) is the potential for opioid induced ventilatory impairment (OIVI) (Australia and New Zealand College of Anaesthetists Faculty of Pain Medicine 2018). We would recommend sedation soring be undertaken in these patients, as well as standardised order sets as recently recommended by the APSF (Anaesthesia Patient Safety Foundation 2018) and ANZCA (Australia and New Zealand College of Anaesthetists Faculty of Pain Medicine 2018).

In summary, cannabinoids may improve pain relief as part of multi-modal approach. There is an increased risk of adverse side effects including increased sedation and subsequent ventilatory impairment.

\section{The future of CBMS}

Further clarification on the role of non-CBD CBMs is expected later this year with the forthcoming UNODC vote on rescheduling as recommended by the WHO, increasing the focus on this group of medicines. With time, this may help to improve the evidence base, define clinical indications including potential therapeutic applications in perioperative medicine and provide outcome data from longer term use, which is currently lacking (Health Products Regualtory Authority 2017; Fitzcharles and Eisenberg 2018).

This latter point is arguably the most important, and whilst cannabis use per se has been associated with some cancers (prostate, glioma, cervical) and psychiatric morbidity, the quality of the evidence is limited, and it is uncertain if long-term effects of CBMs can be extrapolated from long term cannabis use (Nugent et al. 2017; National Academies of Sciences Engineering and Medicine 2017; Campbell et al. 2018).

Therefore, further research is required, and whilst one of the longest follow up studies of cannabis use in a medical setting (Ware et al. 2015) suggested no difference in serious adverse events between controls and cannabis users, the short duration of this and other studies involving CBMs limits conclusions on long-term safety (Hauser et al. 2018c). Long-term data on CBMs is now being collected through patient registries (national and pharmaceutical led) and observational studies providing reporting of adverse effects (Krcevski-Skvarc et al. 2018). Achieving greater clarity on the benefits and harms of CBMs may be affected by the legalisation of cannabis for recreational use in some territories (United Nations Office on Drugs and Crime 2018).

\section{Conclusions}

There are marked discrepancies in the literature regarding grading of the evidence base and the strength and quality of the resultant recommendations.

It is clear that with the increasing trend for legalisation of this class of medicines, and the large number of patients we as a specialty are involved with, the perioperative team need to have a broader understanding of the pharmacology interactions, and potential uses this group of drugs has.

As the evidence base increases, CBMs could become part of the perioperative teams' armamentarium to help provide an opiate sparing multimodal analgesia regime as well as having a role in the management of common postoperative complications such as nausea and vomiting.

\section{Abbreviations}

BIS: Bispectral Index; CB: Cannabinoid; CBD: Cannabidiol; CBN: Cannabinol; CBM: Cannabis-based medicines; CYP: Cytochrome P450; D8THC: Delta-8tetrahydrocannabinol; D9THC: Elta-9-tetrahydrocannabinol;

EEG: Electroencephalogram; GABA: Gamma amino butyric acid; HPRA: Health Products Regulatory Authority; MA: Meta-analysis; MS: Multiple sclerosis; NASEM: National Academies of Science Engineering and Medicine; NNT: Number needed to treat; NNTH: Number needed to harm; PONV: Postoperative nausea and vomiting; RCT: Randomised controlled trial; SR: Systematic review; THC: Tetrahydrocannabinol; UK: United Kingdom; USA: United States of America; WHO: World Health Organisation

\section{Acknowledgements}

Not applicable.

Authors' contributions

SK conceived the idea for the manuscript, both authors acquired, analysed and interpreted the data. Both authors wrote and approved the manuscript.

Authors' information

PT is a Clinical Fellow in Anaesthesia at Sunnybrook Health Sciences Centre. SK is a Consultant Anaesthetist at University Hospital Southampton.

Funding

Not applicable.

Availability of data and materials Not applicable. 


\section{Ethics approval and consent to participate}

Not applicable.

\section{Consent for publication}

Not applicable.

\section{Competing interests}

The authors declare that they have no competing interests.

\section{Author details}

${ }^{1}$ Department of Anaesthesia, Sunnybrook Health Sciences Centre, Bayview Avenue, Toronto, Canada. ${ }^{2}$ Shackleton Department of Anaesthesia, University Hospital Southampton, Tremona Road, Southampton, UK.

Received: 28 July 2019 Accepted: 16 October 2019

Published online: 06 December 2019

\section{References}

Abrams DI. Integrating cannabis into clinical cancer care. Curr Oncol. 2016; 23:S8-14.

Abrams DI. The therapeutic effects of Cannabis and cannabinoids: an update from the National Academies of Sciences, Engineering and Medicine report. Eur J Intern Med. 2018;49:7-11.

Abrams DI, Couey P, Shade SB, Kelly ME, Benowitz NL. Cannabinoid-opioid interaction in chronic pain. Clin. Pharmacol Ther. 2011;90:844-51.

Aguilar BS, Gutiérrez V, Sánchez L, Nougier M. Medicinal cannabis policies and practices around the world. International Drug Policy Consortium. 2018. http:// fileserver.idpc.net/library/Medicinal\%20cannabis\%20briefing_ENG_FINAL.PDF. .

Anaesthesia Patient Safety Foundation. Using the 2018 guidelines from the Joint Commission to kickstart your hospitals program to reduce opioid induced ventilatory impairment. 2018. https://www.apsf.org/article/using-the-2018guidelines-from-the-joint-commission-to-kickstart-your-hospitals-program-toreduce-opioid-induced-ventilatory-impairment/ Accessed 8 Sept 2019.

Anderson GD, Chan L. Pharmacokinetic drug interactions with tobacco, cannabinoids and smoking cessation products. Clin Pharmacokinet. 2016;55: 1353-68.

Aragona $\mathrm{M}$, Onesti $\mathrm{E}$, Tomassini $\mathrm{V}$, et al. Psychopathological and cognitive effects of therapeutic cannabinoids in multiple clerosis: A double-blind, placebo controlled, crossover study. Clin Neuropharmacol. 2009;32:41-7.

Argentinian government. Enrollment in the National Register of Patients in Cannabis Treatment. Government of Argentina. 2018. https://www.argentina. gob.ar/inscribirse-en-el-registro-nacional-de-pacientes-en-tratamiento-concannabis-recann. Accessed 24 Nov 2018.

Ashton CH. Adverse effects of cannabis and cannabinoids. Br J Anaesth. 1999;83: 637-49.

Atwal N, Casey SL, Mitchell VA, Vaughan CW. Neuropharmacology THC and gabapentin interactions in a mouse neuropathic pain model. Neuropharmacology. 2017:144:115-21.

Australia and New Zealand College of Anaesthetists Faculty of Pain Medicine. Position statement on the use of slow release opioid preparations in the treatment of acute pain. 2018. http://www.anzca.edu.au/resources/ endorsed-guidelines/position-statement-on-the-use-of-slow-release-opio Accessed 10 Sept 2019

Australia and New Zealand College of Anaesthetists Faculty of Pain Medicine. Statement on principles for identifying and preventing opioid induced ventilatory impairment (OIVI). http://www.anzca.edu.au/resources/endorsedguidelines/oivi-statement Accessed 12 Sept 2019.

Australian Government Department of Health. Therapeutic Goods Administration. Access to medicinal cannabis products. Austalian Government. 2018. http:// www.tga.gov.au/access-medicinal-cannabis-products-1. Accessed 4 Sept 2019

Aviram J, Samuelly-Leichtag G. Efficacy of Cannabis-based medicines for pain management: a systematic review and meta-analysis of randomized controlled trials. Pain Physician. 2017;20:E755-96.

Bakas T, Van Nieuwenhuijzen PS, Devenish SO, Mcgregor IS, Arnold JC, Chebib M. The direct actions of cannabidiol and 2-arachidonoyl glycerol at GABA A receptors. Pharmacol. Res. 2017:119:358-70.

Barnes MP. The case for medical cannabis - an essay. BMJ. 2018;362:k3230.

Beaulieu P. Effects of nabilone, a synthetic cannabinoid, on postoperative pain. Can J Anesth. 2006;53(8):769-75.

Beaulieu P, Boulanger A, Desroches J, Clark AJ. Medical cannabis: considerations for the anesthesiologist and pain physician. Can J Anaesth. 2016;63:608-24.
Bie B, Wu J, Foss JF, Naguib M. An overview of the cannabinoid type 2 receptor system and its therapeutic potential. Curr Opin Anesthesiol. 2018;31:407-14.

Bilkei-Gorzo A, Albayram O, Ativie F, Chasan S, Zimmer T. Cannabinoid 1 receptor signaling on GABAergic neurons influences astrocytes in the ageing brain. PLoS One. 2018;13(8):1-21.

Brand PA, Paris A, Bein B, et al. Propofol sedation is reduced by 89 tetrahydrocannabinol in mice. Anesth Analg. 2008;107:102-6.

Brazilian Government. Anvisa sets rules for sale of cannabidiol based medicine. Government of Brazil. 2016. http://www.brasil.gov.br/noticias/saude/2016/11/ anvisa-define-regras-para-venda-de-medicamentos-a-base-de-canabidiol. .

Bridgeman MB, Abazia DT. Medicinal cannabis: history, pharmacology, and implications for the acute care setting. Pharm. Ther. 2017:42:180-8.

Broich K. Annual Report 2017/18. Federal Institute for Drugs and Medical Devices. 2018. https://www.bfarm.de/SharedDocs/Downloads/EN/BfArM/ Publikationen/AnnualReport2017-18.pdf?_blob=publicationFile\&v=4.

Bryson EO, Frost EAM. The perioperative implications of tobacco, marijuana, and other inhaled toxins. Int Anesthesiol Clin. 2011:49:103-18.

Buggy DJ, Toogood L, Maric S, Sharpe P, Lambert DG, Rowbotham DJ. Lack of analgesic efficacy of oral $\delta$-9-tetrahydrocannabinol in postoperative pain. Pain. 2003;106:169-72.

Campbell G, Hall WD, Peacock A, et al. Effect of cannabis use in people with chronic non-cancer pain prescribed opioids: findings from a 4-year prospective cohort study. Lancet Public Health. 2018;3:e341-50.

Chesher GB, JAckson DM, Starmer GA. Interaction of cannabis and general anaesthetic agents in mice. Br J Pharmacol. 1974;50:593-9.

Cohen K, Abraham W, Aviv W. Modulatory effects of cannabinoids on brain neurotransmission. Eur J Neurosci. 2019. https://doi.org/10.1111/ejn.14407.

Constitutional Court of South Africa. Minister of Justice and Constitutional Development and others v Prince CCT108/17. Constitutional Court of South Africa. 2017. https://www.concourt.org.za/index.php/judgement/260-ministerof-justice-and-constitutional-development-and-others-v-prince-cct108-17. Accessed 4 Sept 2019

Dame Sally Davies. The therapeutic and medicinal benefits of Cannabis based products-a review of recent evidence. London: Cannabis Scheduling Review Part 1; 2018.

David JM. Medical Marijuana the evidence, clinical practice and its consequences. AAFP national conference. 2017. https:/www.aafp.org/dam/AAFP/documents/ events/nc/handouts/nc17-med-marijuana.pdf. Accessed 24 Sep 2018.

Department of Agriculture, Forestry and Fisheries. Agriculture, Forestry and Fisheries on Constitutional Court ruling on decriminalisation of cultivation and use of cannabis in SA. . South African Government. 2018. https://www. gov.za/speeches/agriculture-forestry-and-fisheries-constitutional-court-rulingdecriminalisation. Accessed 4 Sept 2019

Department of Health and Social Care. Medical cannabis: information and resources. UK government. 2018. https://www.gov.uk/government collections/medicinal-cannabis-information-and-resources Accessed 28 August 2019

Department of Health Ireland. Clinical Guidance on Cannabis for Medical Use. Department of Health Ireland. 2018. https://health.gov.ie/wp-content/ uploads/2018/07/Clinical-guidance-on-cannabis-for-medical-use.pdf. Accessed 24 Nov 2018

Devinsky O, Croos H, Laux L, et al. Trial of cannabidiol for drug-resistant seizures in the Dravet syndrome. N Engl J Med. 2017;376:2011-20.

Devinsky O, Patel AD, Cross JH, et al. Effect of cannabidiol on drop seizures in the Lennox-Gastaut syndrome. N Engl J Med. 2018;378:1888-97.

Dickerson SJ. Cannabis and its effect on anesthesia. J Am Assoc Nurse Anesth. 1980;48:526-8

Expert Committee on Drug Dependence. Cannabidiol (CBD) critical review report. Geneva: World Health Organization; 2018.

Ferreira RCM, Castor MGM, Piscitelli F, Di Marzo V, IDuarte IDG, Romero TRL. The involvement of the endocannabinoid system in the peripheral antinociceptive action of ketamine. J. Pain. 2018;19:487-95.

Fitzcharles MA, Eisenberg E. Medical cannabis: a forward vision for the clinician. Eur J Pain. 2018:22:485-91.

Flisberg P, Paech MJ, Shah T, Ledowski T, Kurowski I, Parsons R. Induction dose of propofol in patients using cannabis. Eur J Anaesthesiol. 2009;26:192-5.

Ghebreyesus TA. Forty first meeting of the expert committee on drug dependence; Director General Letter. Switzerland: World Health Organisation; 2019. https://www.who.int/medicines/access/controlled-substances/UNSG_ letter ECDD41 recommendations_cannabis_24Jan19.pdf?ua=1. Accessed 27 Feb 2019 
Gloss D, Vickrey B. Cannabinoids for epilepsy (Review). Cochrane Database Syst Rev 2014; 3: Art. No.: CD009270.

Government of Argentina. What will cannabis regulation be like in Argentina? 2019. https://www.argentina.gob.ar/noticias/como-sera-la-regulacion-decannabis-en-argentina Accessed 5th September 2019.

Government of Canada. Mandate letter tracker: delivering results for Canadians. Government of Canada. 2018a. https://www.canada.ca/en/privy-council/ campaigns/mandate-tracker-results-canadians.html?utm_campaign=notapplicable\&utm_medium=vanity-url\&utm_source=canada-ca_results. Accessed 21 Nov 2018

Government of Canada. About Cannabis. Government of Canada. 2018b. https:// www.canada.ca/en/health-canada/services/drugs-medication/cannabis/about. html Accessed 4 Sept 2019.

Government of Mexico. COFEPRIS attends within the framework of its legal attributions, the applications for medicinal, personal and playful use of cannabis. Government of Mexico. 2018a. https://www.gob.mx/cofepris/ articulos/cofepris-atiende-en-el-marco-de-sus-atribuciones-legales-lassolicitudes-para-uso-medicinal-personal-y-ludico-de-la-cannabis-17352 o?idiom=es. Accessed 4 Sept 2019

Government of Mexico. They release 38 products with cannabis and its derivatives. Government of Mexico. 2018b. https://www.gob.mx/cofepris/articulos/iberan-38productos-con-cannabis-y-sus-derivados-182739?idiom=es. Accessed 4 Sept 2019.

Government of Mexico. COFEPRIS attends within the framework of its legal attributions, the request for medicinal, personal and recreational use of cannabis. 2018c. https://www.gob.mx/cofepris/es/articulos/cofepris-atiendeen-el-marco-de-sus-atribuciones-legales-las-solicitudes-para-uso-medicinalpersonal-y-ludico-de-la-cannabis-173520?idiom=es. Accessed 5 Sept 2019

Government of the Netherlands. Controlled cannabis supply chain experiment. 2019. https://www.government.nl/topics/drugs/controlled-cannabis-supplychain-experiment Accessed $7^{\text {th }}$ September2019

Guillaud J, Legagneux F, Paulet C, Leoni J, Lassner J. Mortality in Anaesthesia. European Acaemy of Aaesthesiology vol 3 Springer Berlin, Heidelberg. Comparison of Levonantradol 1 or $2 \mathrm{mg}$ IM with Pethdiine and Placebo for postoperative analgesia. 1983

Hallak JEC, Dursun SM, Bosi DC, et al. The interplay of cannabinoid and NMDA glutamate receptor systems in humans : preliminary evidence of interactive effects of cannabidiol and ketamine in healthy human subjects. Prog. Neuropsychopharmacol. Biol. Psychiatry. 2011;35(1):198-202.

Hauser W, Finn DP, Kalso E, et al. European Pain Federation (EFIC) position paper on appropriate use of cannabis-based medicines and medical cannabis for chronic pain management. Eur J Pain. 2018a;22:1547-64.

Hauser W, Finnerup NB, Moore RA. Systematic reviews with meta-analysis on cannabis-based medicines for chronic pain: a methodological and political minefield. Pain. 2018c;159:1906-7.

Hauser W, Petzke F, Fitzcharles MA. Efficacy, tolerability and safety of cannabisbased medicines for chronic pain management-an overview of systematic reviews. Eur J Pain. 2018b;22:455-70.

Health Canada. Health products containing cannabis or for use with cannabis: guidance for the Cannabis Act, the Food and Drugs Act, and related regulations. Government of Canada 2018. https://www.canada.ca/en/healthcanada/services/drugs-health-products/drug-products/applicationssubmissions/guidance-documents/guidance-cannabis-act-food-and-drugsact-related-regulations/document.html.

Health Products Regualtory Authority. Cannabis for Medical Use-A Scientific Review. Health Products Regulatory Authority. 2017. https://www.hpra.ie/ docs/default-source/publications-forms/newsletters/cannabis-for-medicaluse\%2D\%2D-a-scientific-review.pdf?sfvrsn=7.

Heuberger J, Guan Z, Oyetayo OO, et al. Population pharmacokinetic model of THC integrates oral, intravenous, and pulmonary dosing and characterizes short- and long-term pharmacokinetics. Clin Pharmacokinet. 2015;54:209-19.

Holdcroft A, Maze M, Dore C, Tebbs S, Thompson S. A multicenter dose-escalation study of the analgesic and adverse effects of an oral cannabis extract (Cannador) for postoperative pain management. Anesthesiology. 2006;104(5):1040-6.

Hosking RD, Zajicek JP. Therapeutic potential of cannabis in pain medicine. $\mathrm{Br}$ J Anaesth. 2008;101:59-68.

Ibera C, Shalom B, Saifi F, Shruder J, Davidson E. Effects of cannabis extract premedication on anesthetic depth. Harefuah. 2018;157:162-6.

Indian Council of Medical Research, Department of Health Research-Ministry Health and Family Welfare Government of India. Media report November 2018. 2018. https://www.icmr.nic.in/sites/default/files/ICMR_News.pdf Accessed 12th September 2019
International Drug Policy Consortium. The United Nations General Assembly Special Session (UNGASS) on the World Drug Problem. London: Report of Proceedings; 2016.

Jain A, Ryan J, McMahon G, Smith G. Evaluation of intramuscular levonantradol and placebo in acutepostoperative. J Clin Pharmacol. 1981;21:320-6.

Jefferson D, Harding H, Cawich S, Jackson-Gibson A. Postoperative analgesia in the Jamaican cannabis user. J Psychoactive Drugs. 2013;45:227-32.

Kalliomäki J, Segerdahl M, Webster L, et al. Evaluation of the analgesic efficacy of AZD1940, a novel cannabinoid agonist, on post-operative pain after lower third molar surgical removal. Scand. J. Pain. 2013;4:17-22.

Karschner EL, David Darwin W, Goodwin RS, Wright S, Huestis MA. Plasma cannabinoid pharmacokinetics following controlled oral $\Delta$ 9tetrahydrocannabinol and oromucosal cannabis extract administration. Clin Chem. 2011;57:66-75.

Kleine-Brueggeney M, Greif R, Brenneisen R, Urwyler N, Stueber F, Theiler LG. Intravenous Delta-9-tetrahydrocannabinol to prevent postoperative nausea and vomiting: A randomized controlled trial. Anesth Analg. 2015;121:1157-64.

Koppel BS, Brust JCM, Fife T, et al. Systematic review: efficacy and safety of medical marijuana in selected neurologic disorders: report of the Guideline Development Subcommittee of the American Academy of Neurology. Neurology 2014;82:1556-1563

Krcevski-Skvarc N, Wells C, Hauser W. Availability and approval of cannabis-based medicines for chronic pain management and palliative / supportive care in Europe : A survey of the status in the chapters of the European Pain Federation. Eur J Pain. 2018;22:440-54.

Kumar RN, Chambers WA, Pertwee RG. Pharmacological actions and therapeutic uses of cannabis and cannabinoids. Anaesthesia. 2001;56:1059-68.

Kumar SSH, Dass LL, Sharma AK. Cannabis Indica (Bhang) extract as preanaesthetic to propofol anaesthesia in dogs. Journal of Applied Animal Research. 2010;37:125-7.

Laaris N, Good CH, Lupica CR. $\Delta 9$-tetrahydrocannabinol is a full agonist at CB1 receptors on GABA neuron axon terminals in the hippocampus. Neuropharmacology. 2011;59(443):121-7.

Layden JE, Ghinai I, Pray I et al. Pulmonary illness related to e-cigarette use in Illinois and Wisconsin - preliminary report. N Engl J Med 2019. https://doi. org/10.1056/NEJMoa1911614. [Epub ahead of print]

Layeeque R, Siegel E, Kass R, et al. Prevention of nausea and vomiting following breast surgery. Am J Surg. 2006;191:767-72.

Levin DN, Dulberg Z, Chan AW, Hare GM, Mazer D, Hong A. A randomizedcontrolled trial of nabilone for the prevention of acute postoperative nausea and vomiting in elective surgery. Can J Anesth. 2017;64:385-95.

Lewis $\mathrm{H}$, Campbell DN, Barrowcliffe MP. Effect of nabilone on nausea and vomiting after total abdominal hysterectomy. Br J Anaesth. 1994;73:244-6.

Lile J, Wesley M, Kelly T, Hays R. Separate and combined effects of gabapentin and 9THC in humans discriminating 9THC. Behav Pharmacol. 2016;27:215-24.

Liu C, Bhatia A, Buzon-Tan A, et al. Weeding out the problem: the impact of preoperative cannabinoid use on pain in the perioperative period. Anesth Analg. 2018. https://doi.org/10.1213/ANE.0000000000003963.

Lotsch J, Weyer-Menkhoff I, Tegeder I. Current evidence of cannabinoid-based analgesia obtained in preclinical and human experimental settings. Eur. J. Pain. 2018:22:471-84.

Lucas CJ, Galettis P, Schneider J. The pharmacokinetics and the pharmacodynamics of cannabinoids. Br J Clin Pharm. 2018;84:2477-82.

Maguire DR, France CP. Antinociceptive effects of mixtures of mu opioid receptor agonists and cannabinoid receptor agonists in rats : Impact of drug and fixed-dose ratio. Eur J Pharmacol. 2018;819:217-24.

Manzanares J, Corchero J, Romero J, Fernández-Ruiz JJ, Ramos J, Fuentes JA. Pharmacological and biochemical interactions between opioids and cannabinoids. Trends Pharmacol Sci. 1999;20:287-94.

Mead A. The legal status of cannabis (marijuana) and cannabidiol (CBD) under U. S. law. Epilepsy Behav. 2017;70:288-91.

Medicines Control Council. Medicines Control Council clarifies access to Cannabis for the treatment of medical conditions. Medicines Control Council. 2016. https://www.sahpra.org.za/documents/5933cac110.14_Media_Release_ Cannabis_Nov16_v1.pdf Accessed 4 Sept 2019

Meiri $\mathrm{E}$, Jhangiani $\mathrm{H}$, Vredenburgh $\mathrm{JJ}$, et al. Efficacy of dronabinol alone and in combination with ondansetron versus ondansetron alone for delayed chemotherapy-induced nausea and vomiting. Curr Med Res Opin. 2007;23:533-43.

Meng H, Johnston B, Englesakis M, Moulin D, Bhatia A. Selective cannabinoids for chronic neuropathic pain : a systematic review and meta-analysis. Anesth Analg. 2017;125(5):1638-52. 
Mucke M, Phillips T, Radbruch L, Petzke F, Hauser W. Cannabis-based medicines for chronic neuropathic pain in adults (review). Cochrane Database Syst. Rev. 2018;3:CD012182

National Academies of Sciences Engineering and Medicine. The health effects of cannabis and cannabinoids: the current state of evidence nad recommendations for research. Washington, DC: The National Academies Press; 2017.

National Agency for the Safety of Medicines and Health Products. Decree No. 2013-473 of June 5, 2013 modifying as regards pharmaceutical specialties the provisions of Article R. 5132-86 of the Public Health Code relating to the prohibition of transactions relating to cannabis or its derivatives. Government of France. https://www.legifrance.gouv.fr/affichTexte.do?cidTexte= JORFTEXT000027513604\&categorieLien=id. Accessed 24 Nov 2018

National Health Service. Cannabis-based products for medicinal use: Frequently Asked Questions. 2018 https:/www.england.nhs.uk/medicines/support-for-prescribers/ cannabis-based-products-for-medicinal-use/cannabis-based-products-formedicinal-use-frequently-asked-questions/\#what-are-synthetic-cannabinoids-andare-they-included-in-the-re-scheduling Accessed 10 Sept 2019

National Institute for Health and Care Excellence. New guidance to tackle inequalities in multiple sclerosis care. National Institute for Health and Care Excellence. 2014. https://www.nice.org.uk/news/article/new-guidance-totackle-inequalities-in-multiple-sclerosis-care. Accessed 24 Nov 2018.

National Institute for Health and Care Excellence. NICE draft gudiance and NHS England review highlight need for more research on cannabis-based medicinal products. 2019. https://www.nice.org.uk/news/article/nice-draftguidance-and-nhs-england-review-highlight-need-for-more-research-oncannabis-based-medicinal-products Accessed 25 Sept 2019.

New Zealand Ministry of Health. Prescribing cannabis-based products. New Zealand Government: 2018. https://www.health.govt.nz/our-work/regulationhealth-and-disability-system/medicines-control/medicinal-cannabis/ prescribing-cannabis-based-products. Accessed 4 Sept 2019

New Zealand Parliament. Changes to New Zealand's drug laws proposed by medicinal cannabis bill. New Zealand Government. 2018. https:/www. parliament.nz/en/get-involved/topics/all-current-topics/changes-to-newzealand-s-drug-laws-proposed-by-medicinal-cannabis-bill. Accessed 4 Sept 2019

Nielsen S, Germanos R, Weier M, et al. The use of cannabis and cannabinoids in treating symptoms of multiple sclerosis: a systematic review of reviews. Curr Neurol Neurosci Rep. 2018;18:8.

Nugent SM, Morasco BJ, O'Neil ME, et al. The effects of cannabis among adults with chronic pain and an overview of general harms a systematic review. Ann Intern Med. 2017;167:319-31.

Office of Medicinal Cannabis. Medicinal Cannabis. Netherlands Ministry of Health. 2018. https://english.cannabisbureau.nl/ Accessed 4 Sept 2019

Office of Medicinal Cannabis Government of the Netherlands. Patients guide medicinal cannabis. 2019. https://english.cannabisbureau.nl/documents/ circulars/2018/02/20/patientsquide-medicinal-cannabis Accessed 13 Sept 2019

Ostenfeld T, Price J, Albanese $\mathrm{M}$, et al. A randomized, controlled study to investigate the analgesic efficacy of single doses of the molar tooth extraction. J. Clin. Pain. 2011;27(8):668-76

Pacheco F, Roberto T, Romero L, Dimitri I, Duarte G. Ketamine induces central antinociception mediated by endogenous cannabinoids and activation of CB 1 receptors. Neurosci. Lett. 2019;699:140-4.

Pertwee R. Handbook of Cannabis. Oxford Scholarship online. 2015. http://www. oxfordscholarship.com/view/10.1093/acprof:oso/9780199662685.001.0001/ acprof-9780199662685. Subscription required. Accessed 28 Jan 2019

Pertwee RG, Howlett AC, Abood ME, et al. International union of basic and clinical pharmacology . LXXIX. Cannabinoid receptors and their ligands: beyond CB 1 and CB 2. Pharmacol Rev. 2010;62:588-631.

Republic of Phillipines House of Representatives. An act providing compassionate and right of access to medical cannabis and expanding research into its medicinal properties. Government of Phillipines. 2018. Congress.gov.ph/ legisdocs/first_17/CR00402.pdf Accessed 15 Sept 2019

Reynolds JR. Therapeutical uses and toxic effects of cannabis indica. Lancet. 1890; 135:637-8.

Rice J, Cameron M. Cannabinoids for treatment of MS symptoms: state of the evidence. Curr Neurol Neurosci Rep. 2017;18:1-10.

Richtig G, Bosse G, Arlt F, Heymann CV. Cannabis consumption before surgery may be associated with increased tolerance of anesthetic drugs: A case report. Int J Case Rep. 2015;6:436-8.

Rodríguez-Muñoz M, Sánchez-Blázquez P, Merlos M, Garzon-Nino J. Endocannabinoid control of glutamate NMDA receptors : the therapeutic potential and consequences of dysfunction. Oncotarget. 2016;34:55840-62.
Rong C, Carmona NE, Lee YL, et al. Drug-drug interactions as a result of coadministering $\triangle 9-T H C$ and CBD with other psychotropic agents. Expert Opin Drug Saf. 2017;17:51-4.

Sánchez-Blázquez P, Rodríguez-Muñoz M, Garzón J. The cannabinoid receptor 1 associates with NMDA receptors to produce glutamatergic hypofunction : implications in psychosis and schizophrenia. Front. Pharmacol. 2014;4:1-10.

Scavone J, Sterling R, Van Bockstaele E. Cannabinoid and opioid interactions: implications for opiate dependence and withdrawal. Neuroscience. 2013;248:637-54.

Schelling G, Hauer D, Azad SC, et al. Effects of general anesthesia on anandamide blood levels in humans. Anesthesiology. 2006;104(2):273-7.

Schuster J, Ates M, Brune K, Gühring H. The cannabinoids R(-)-7-hydroxy-delta-6tetra-hydrocannabinol-dimethylheptyl (HU-210), 2-Oarachidonoylglycerylether (HU-310) and arachidonyl-2-chloroethylamide (ACEA) increase isoflurane provoked sleep duration by activation of cannabinoids 1 (CB1)-recep. Neuroscience Letters. 2002;326:196-200.

Seeling W, Kneer L, Buchele B, et al. Delta(9)-tetrahydrocannabinol and the opioid receptor agonist piritramide do not act synergistically in postoperative pain. Der Anästhesist. 2006;55:391-400.

Smith L, Azariah F, Lavender V, Stoner N, Bettiol S. Cannabinoids for nausea and vomiting in adults with cancer receiving chemotherapy (Review). Cochrane Database Syst Rev. 2015; 11: Art. No. CD009464

Stevens AJ, Higgins MD. A systematic review of the analgesic efficacy of cannabinoid medications in the management of acute pain. Acta Anaesth Scand. 2017;61:268-80.

Stockings E, Campbell G, Hall WD, et al. Cannabis and cannabinoids for the treatment of people with chronic non-cancer pain conditions. Pain. 2018a; 159:1932-54

Stockings E, Zagic D, Campbell G, Weier M, Hall WD, Nielsen S, Herkes GK, et al. Evidence for cannabis and cannabinoids for epilepsy: a systematic review of controlled and observational evidence. J Neurol Neurosurg Psychiatr. 2018b; 89:741-53.

Stoelting R, Martz R, Gartner J, Creasser C, Brown D, Forney R. Effects of delta-9tetrahydrocannibinol on Halothane MAC in dogs. Anesthesiology. 1973;35:521-4.

Symons I. Cannabis smoking and anaesthesia. Anaesthesia. 2002;57:1142

Tham SM, Angus JA, Tudor EM, Wright CE. Synergistic and additive interactions of the cannabinoid agonist CP55,940 with $\mu$ opioid receptor and a 2-adrenoceptor agonists in acute pain models in mice. Br. J. Pharmacol. 2005;144(6):875-84.

Therapeutic Goods Administration. Guidance for the use of medicinal cannabis in Australia Overview. Woden ACT: Australian Government Department of Health; 2017. Version 1

Thiele EA, Marsh ED, French JA, et al. Cannabidiol in patients with seizures associated with Lennox-Gastaut syndrome (GWPCARE4): a randomised, double-blind, placebo-controlled phase 3 trial. The Lancet. 2018;391:1085-96.

Transnational Institute, Global Drug Policy Observatory. UNGASS 2016: a broken or broad consensus? UN summit cannot hide growing divergence in the global drug policy landscape. Amsterdam: United Nations; 2016.

Turcotte D, Doupe M, Torabi M, et al. Nabilone as an adjunctive to gabapentin for multiple sclerosis-induced neuropathic pain : a randomized controlled trial. Pain Med. 2015:16:149-59.

Ujváry I, Hanuš L. Human metabolites of cannabidiol: a review on their formation, biological activity, and relevance in therapy. Cannabis Cannabinoid Res. 2016; 1(1):90-101.

United Nations Office on Drugs and Crime. Global overview of drug demand and supply. Latest trends, cost-cutting issues. United Nations; 2018. https://www. unodc.org/wdr2018/. Accessed 24 Jan 2019.

United Nations Office on Drugs and Crime. World drug report 2019 Cannabis and Hallucinogens. 2019. https://wdr.unodc.org/wdr2019/prelaunch/WDR19 Booklet_5_CANNABIS_HALLUCINOGENS.pdf. Accessed 15 Sept 2019

Uruguay Government. Ministry of Public Health authorized the sale of medicinal cannabis to a company that met the requirements. Government of Uruguay. 2018. https://www.presidencia.gub.uy/comunicacion/comunicacionnoticias/ salud-cannabis-medicinal-venta-empresa-requisitos-basso-msp-ircca. Accessed 4 Sept 2019.

US Food and Drug Administration. FDA and marijuana. In: US Food and Drug Administration; 2016. https://www.fda.gov/NewsEvents/PublicHealthFocus/ ucm421163.htm. Accessed 15 Nov 2018

US Food and Drug Administration. Press announcements_FDA approves first drug comprised of an active ingredient derived from marijuana to treat rare, severe forms of epilepsy. US Food and Drug Administration. 2018 https:// www.fda.gov/NewsEvents/Newsroom/PressAnnouncements/ucm611046.htm Accessed 24 Jan 2019. 
US Food and Drug Administration. Vaping Illnesses: consumers can help protect themselves by avoiding Tetrahydrocannabinol (THC) containing vaping products. 2019. https://www.fda.gov/consumers/consumer-updates/vapingillnesses-consumers-can-help-protect-themselves-avoidingtetrahydrocannabinol-thc-containing Accessed 9 Sept 2019.

Vandrey R, Herrmann ES, Mitchell JM, et al. Pharmacokinetic profile of oral cannabis in humans: blood and oral fluid disposition and relation to pharmacodynamic outcomes. J Anal Toxicol. 2017;41:83-99.

Ware MA, Wang T, Shapiro S, Collet J. Cannabis for the management of pain: assessment of safety study(COMPASS). J. Pain. 2015;16:1233-42.

Whiting PF, Wolff RF, Deshpande S, et al. Cannabinoids for medical use: a systematic review and meta-analysis. JAMA. 2015;313:2456-73.

WHO Expert Committee on Drug Dependence. Critical review: Delta-9tetrahydrocannabinol. World Health Organisation. 2018. https:/www.who.int/ medicines/access/controlled-substances/THCv1.pdf?ua=1. Accessed 24 Nov 2018.

Yeon Kong T, Kim JH, Kyun Kim D, Suk LH. Synthetic cannabinoids are substrates and inhibitors of multiple drug-metabolizing enzymes. Arch Pharm Res. 2018; 41:691-710.

Zendulka O, Dovrtělová G, Nosková K, et al. Cannabinoids and cytochrome P450 interactions. Curr Drug Metab. 2016;17:206-26.

Zlas J, Stark H, Seligman J. Early medical use of cannabis. Nature. 1993;363:215.

\section{Publisher's Note}

Springer Nature remains neutral with regard to jurisdictional claims in published maps and institutional affiliations.

Ready to submit your research? Choose BMC and benefit from:

- fast, convenient online submission

- thorough peer review by experienced researchers in your field

- rapid publication on acceptance

- support for research data, including large and complex data types

- gold Open Access which fosters wider collaboration and increased citations

- maximum visibility for your research: over $100 \mathrm{M}$ website views per year

At BMC, research is always in progress.

Learn more biomedcentral.com/submissions 